\title{
The Evaluation of Production Safety of Coal-mining Region
}

\author{
Kudrevatykh Natalya V., Sheveleva Oksana B. ${ }^{\text {b }}$ \\ Finance and credit Department \\ T. F. Gorbachev Kuzbass State Technical University \\ Kemerovo, Russian Federation \\ aknv.fk@yandex.ru, bsheveleva_oxana@list.ru
}

\begin{abstract}
The existing external economic situation in the country, the offer to create in Eastern Siberia "a carbon-free zone" will have a negative impact on production safety in the Kemerovo region - the largest coal-mining region of the country. The aim of the research is to assess the real situation in production safety of the region and to justify the need to develop measures for its increase. In the article, the assessment of the production safety of the Kemerovo region is carried out by its main criteria: the actual level of production decline during the considered period, the current state of the fixed industrial assets, the comparative investments amount and behavior. The results of the study revealed that along with the positive movements in the Kemerovo region's economy in the recent years there began to show problems and constraints in the effective functioning of the industrial facilities mainly under the influence of geopolitical factors in relation to production safety. The level of production safety of the Kemerovo region, despite the existence of a significant amount of natural resources, is in crisis. The research results can be used for development of the strategy of development of the region.
\end{abstract}

Keywords - coal-mining region; production safety; fixed assets; investments; economic security.

\section{INTRODUCTION}

The term "economic security" is a component of a broader concept that is of "national security". It has been taken as an important criterion in relation to the group of states, a single country, a region, an economical facility, and an individual relatively recently. In many respects it is connected with transition of the world community from the paradigm of the public progress to ensuring the development of an individual.

The problem of economic security troubles the minds of many philosophers, economists and politicians such as Democritus, Aristotle, Platon and others. The foundation of modern views on the society safety in the 20th century was laid by works of V. Pareto and an outstanding Russian scientist A. Bogdanov.

In Russia, a high interest in problems of strengthening the economic security arose in the last decade of the 20th century. It was connected with the beginning of economic transformations and the system crisis of the Russian economy [1-14]. Particularly, the regional aspect of economic security was separately investigated [15-24].

As a part of the economic security of the region, the following types of regional security are identified production, social and economic, financial, ecological, power, transport, information, food, etc.

In spite of the fact that the production safety is the basis of the economic security of the region, this aspect is now studied insufficiently, and a number of questions remains sharply debatable.

The production safety is often identified with the industrial safety. But these concepts don't substitute each other at all. Thus, when we speak of the industrial safety, we must understand the safety of production. While the production safety assumes safety of the region in the sphere of its own production development potential.

\section{METHODS}

In the study, the systemic and economical and statistical methods are applied.

The purpose of the work is to assess the production safety of the coal-mining system region and justify the need to develop and improve the system supporting the production safety of the region based on the development of the priority areas of the regional economy.

For the solution of the set goals the following tasks have been solved:

1. The assessment of the production safety of the region has been given by the main criteria: the actual level of decline in production during the considered period; current state of the fixed production assets; the comparative size and behavior of production investments.

2. The main threats of production safety of the Kemerovo region have been identified.

3. The necessity of the improvement of the production safety support system as the basis of the economic security of the region has been proved.

In the work such scientific methods as statistical supervision, analysis and synthesis, system approach have been applied. 


\section{RESULTS}

The conducted research has allowed to reveal the main threats of production safety of the coal-mining region, on the example of the Kemerovo region:

1) raw orientation of the region;

2) decrease in production, including in the key branches of industry;

3) high depreciation of fixed assets;

4) insufficient investment activity.

\section{DISCUSSIONS}

The state of the productive safety has a significant impact on the level of the economic security of the region which in turn affects the level of its sustainable development. This is due to the fact that the production ensures satisfaction of numerous current and strategic needs of the territory and its population.

Analysis of the production safety is specific on the regional level. Thus, if in the national scale we should strive continuously for comprehensive development of a large number of industries in order to ensure the sufficient level of independence from other states. But within the limits of one territory you can be restricted with the several aspects of economic activities, which had been historically developed on the considered territory.

These priority areas of management should be used as a primary mechanism for improving the region's competitiveness and the achievement of its strategic objectives.

Secondary industries also need to be developed, but the challenges facing them should be less "ambitious", for example, aimed at full or partial satisfaction of the internal needs of the territory.

It is undeniable that Kuzbass has been and remains a coal-mining region. Today the Kemerovo region accounts for $58.3 \%$ of coal production in Russia, $72.7 \%$ of the production of coking coal, and by the whole group of valuable grades of the coking coal $-100 \%$.

But, in addition, the Kemerovo region in Russia is: more than $12 \%$ of iron and $7.5 \%$ of steel, $23 \%$ of long-rolled steel, $11 \%$ aluminum and $22 \%$ of coke, $56 \%$ ferrosilicon, more than $10 \%$ of chemical fibers and threads, $100 \%$ mine scraper conveyors, $70 \%$ of Russian coal exports [25].

It is a production of basic specialized industries in the region : metallurgy, chemistry, and the coal mining.

Over the years, these export-oriented industries allowed to meet the needs of the coal-mining region.

But the situation on the foreign market requires from the regions including mining to deal with the development of socalled "minor" branches.

Today's realities dictate the need for development in the region coal processing industry, agriculture, construction, transport, communications and others.
Under these conditions, it is especially important to solve the problem of ensuring the production safety of the region.

The main competitive advantages of the Kemerovo region, which has a positive effect on its production safety, include:

- a high level of industrial development;

- high availability of natural resources and raw materials;

- $\quad$ preservation of the positive dynamics of some macroeconomic indicators, the prospects for maintaining and expanding the positive dynamics in the long term;

- well-developed infrastructure (a dense network of roads, developed urban centers, etc.)

Production safety is characterized by the presence of the resource base, the conditions that ensure the integration processes, speeding up of the reproduction system in an objectively existing specialization of the region. [26]

The following is assessed for the analysis of the production safety:

- The actual level of decline in production during the survey period;

- $\quad$ the direction of the changes in the sector structure of the regional economy, its industry, agriculture, construction and transport, reflecting the crisis in their respective industries;

- the current state of fixed assets;

- the relative magnitude and dynamics of productive investment.

Furthermore, the basic components of the production safety of the Kemerovo region have been considered.

The recession rate (expressed as a percentage reduction in the volume) of industrial, agricultural and construction production, traffic volumes stands as the criteria characteristic of the regional crisis, reflecting the degree of destruction of the productive capacity of the territory.

The threshold pre-crisis value of the relative decline in production within a specified calculation period is $4 \%$ on average per year for industrial and construction products, the volume of traffic, the crisis value is $6 \%$, for agricultural production -5 and $7 \%$ respectively [27].

In order to assess the actual level of decline / rise in the production of the region an indicator of turnover of the organisations can be used.

The turnover of the Kemerovo region organizations tends to have a slight increase (107.8\% in 2014 in comparison with 2013 year, $107.6 \%$ in 2015 compared with 2014 year). This is due, largely, to the currency exchange rate growth that affects the dynamics of the export turnover.

Economic sectors which reacted to the change in the situation dramatically are mainly focused on domestic demand.

In the region there is a crisis condition in the following industries: 
1) Fisheries (decline in production by $17.58 \%$ in 2015 compared to the year 2014);

2) Production of leather, leather products and footwear (decline in production by $38.97 \%$ );

3) Production of rubber and plastic products (decline in production by $20.97 \%$ );

4) Production of vehicles and equipment (drop in production by $50.59 \%$ );

5) Construction (decline in production by $9.65 \%$ );

6) wholesale and retail trade; repair of motor vehicles, motorcycles, household goods and personal items (a drop in production to $9.48 \%$ ) [calculated by the author according to the data of 28].

Taking into consideration the critical degree of depreciation of fixed assets to $40 \%$, the majority of enterprises of the Kemerovo region have a significantly higher indicator.

This situation reflects not only the technological backwardness, but also has a significant impact on productivity and work safety.

In 2014 the greatest degree of depreciation of fixed asset was observed in such sectors as generation and distribution of electricity, gas and water (over 67\%); transport and communications $(60.3 \%$ more $)$; construction $(60 ., 5 \%)$; mining (53.7\%).

A positive aspect for the regional economy as a whole, and safety, in particular, was the growth of investments in 2014 (in 2013 in comparison with 2012 their amount decreased by 36,390 million rubles or $20.59 \%$ ).

But if the increase was $17.3 \%$ in 2014 (an increase of 24,253 million rubles), the number of branches significantly dropped in their dynamics so, in 2014 (compared to 2013) there was a decrease of investments in fixed assets in such areas as:

- agriculture, hunting and forestry $(10.5 \%)$;

- extraction of fuel and energy minerals $(22.7 \%)$;

- manufacture of food products, beverages and tobacco $(34.4 \%)$;

- textile and clothing industry (10.3\%);

- wood processing and manufacture of wood products $(30.4 \%)$;

- pulp and paper production, publishing and printing (73.6\%);

- manufacture of coke and petroleum products (by $40.8 \%$ );

- chemical industry $(16.8 \%)$;

metallurgical production and production of finished metal products $(40 \%)$

- construction $(58.6 \%)$;

- hotels and restaurants $(62.5 \%)$;

- financial activities $(6.3 \%)$;

- operations with real estate, renting and business activities $(25.2 \%)$;

- public administration and defense, social security
$(25.2 \%)$;

- medical and social services $(43.8 \%)$.

The greatest growth occurred in investment activities such as:

- mining operations, except energy (93.3\%);

- manufacture of rubber and plastic products (3.13 times);

- manufacture of other non-metallic mineral products $(16.4 \%)$;

- manufacture of machinery and equipment (27.6\%);

- manufacture of electrical and optical equipment $(30 \%)$;

- manufacture of transport equipment (53.6\%);

- the production and distribution of electricity, gas and water (4.91times);

- wholesale and retail trade; repair of motor vehicles, motorcycles, household goods and personal items (by 2.1 times) [authors calculated according to 28].

The emerging positive dynamics of investment flows into the region's economy changed in 2015. According to the data for January - September 2015, the investment in fixed assets amounted to 80,557 million rubles. In comparison, the volume of investments in 2012 amounted to 176,741 million rubles, in 2013 - 140,351 million rubles, in $2014-164,604$ million rubles [28].

\section{CONCLUSION}

To sum up, it should be noted that along with the positive movements in the economy of Kemerovo region some problems and restrictions have appeared under the influence of mainly geopolitical factors. The effective functioning of the industrial potential within the boundaries of the so-called industrial safety have begun to be shown in recent years. It is the industrial safety that is one of the objectives of the economic development. And in this case, the system of indicators and criteria of the production safety set rather strict conditions to ensure that recently has become problematic.

The level of production safety in the Kemerovo region, despite the presence of significant amounts of natural resources, is in crisis.

The main threats of the Kemerovo Region industrial safety are:

1) raw material orientation of the region;

2) reduction of production, including the basic industries;

3) higher depreciation of fixed assets;

4) lack of investment activity.

The above leads to the conclusion that up to date industrial security requires a significant attention and development of measures aimed at its stabilization, enabling it to become a major factor of sustainable development of Kuzbass. 


\section{REFERENCES}

[1] Abalkin L. I. Ehkonomicheskaya bezopasnost' Rossii: ugrozy i ih otrazhenie [The economic security of Russia: threats and their reflection]. Voprosy ehkonomiki. 1994.\#12. p. 4-13.

[2] Arhipov A., Gorodeckij A., Mihajlov B. Ehkonomicheskaya bezopasnost': ocenki, problemy, sposoby obespecheniya [Economic security: assessment of problems, ways to ensure]. Voprosy ehkonomiki. 1994. \#12. p. 36-44.

[3] Belozerov I. P., Klokov E. A. Mesto i znachimost' ehkonomicheskoj bezopasnosti v strukture nacional'noj bezopasnosti Rossii [Place and importance of economic security in the structure of Russia's national security]. Vestnik Omskogo universiteta. Seriya «Ehkonomika». 2009. \# 2. p. 94-100. (rus)

[4] Butorin V. K., Tkachenko A.N., Bebko A.N., Konoplev V.A., Skryl' K.V., Zhdanov V.N., Shipilov S.A. Osnovy ehkonomicheskoj bezopasnosti: v 3 tomah [Economic security essentials]. - Kemerovo - Moskva: Izdatel'skoe ob"edinenie «Rossijskie universitety»: «Kuzbassvuzizdat - ASTSH». 2007. \# 1047 s. (rus)

[5] Buhval'd E., Golovackaya N., Lazarenko S. Makroaspekty ehkonomicheskoj bezopasnosti: faktory, kriterii i pokazateli [Significant issues of economic security: factors, criteria and indicators]. Voprosy ehkonomiki. 1994. \# 12. p. 25-44. (rus)

[6] Vechkanov G. S. Ehkonomicheskaya bezopasnost' [Economic security]. Moskva. 2007. \# 384 s. (rus)

[7] Dronov R. Podhody k obespecheniyu ehkonomicheskoj bezopasnosti [Approaches to economic security]. Ehkonomist. 2001. \# 2. p. 36-44. (rus)

[8] Illarionov A. A. Kriterii ehkonomicheskoj bezopasnosti [Criteria for economic security]. Voprosy ehkonomiki. 1998. \# 10. p. 35-58. (rus)

[9] Kozlova A. Ehkonomicheskaya bezopasnost' kak yavlenie i ponyatie [The phenomenon and the concept of economic security]. Vlast'. 2009. \# 1. - p.14-17. (rus)

[10] Kochergina T. E. Ehkonomicheskaya bezopasnost' [Economic security]. Moskva, 2007. \# 445 s. (rus)

[11] Napalkova I. G. Ehkonomicheskaya bezopasnost': institucional'nopravovoj analiz. Monografiya [Economic security: the legal and institutional analysis]. Economic security: the legal and institutional analysis]. Rostov-na-Donu: SKNC VSH, 2006. \# 148 s. (rus)

[12] Ehkonomicheskaya i nacional'naya bezopasnost': uchebnik [Economic and national security] / pod red. E. A. Olejnikova. Moskva, 2004. \# 768 s. (rus)

[13] Romashchenko T. D. Ehkonomicheskaya bezopasnost' nacional'nogo hozyajstva: Teoriya, metodologiya, formirovanie $\mathrm{v}$ Rossii: monografiya [The economic security of the national economy: theory, methodology, formation in Russia]. - Voronezh: Izdatel'stvo Voronezhskogo gosudarstvennogo universiteta. 2003. \# 216 s. (rus)

[14] Senchagov V. K. Ehkonomicheskaya bezopasnost' Rossii [The economic security of Russia]. Moskva: Delo, 2005. \# 896 s. (rus)

[15] Agapova T. N. Metodika i instrumentarij dlya monitoringa ehkonomicheskoj bezopasnosti regiona [Methods and tools for monitoring the economic security of the region]. Voprosy statistiki. 2001. \# 11. p. 44-51. (rus)

[16] Blinov N. M. Ehkonomicheskaya bezopasnost' centra i regionov [Economic security center and regions]. Obshchestvennye nauki. 1996. \# 2. p. 33-34. (rus)

[17] Vik S.V., Skotnikov D. A. Sistema faktorov nacional'noj bezopasnost i metod ocenki ee ehkonomicheskoj sostavlyayushchej (na primere Kemerovskoj oblasti) [The system of national security factors and method of assessing its economic component (in the Kemerovo region)]. Vestnik kuzbasskogo gosudarstvennogo tehnicheskogo univeristeta. 2015. \# 6. - p. 229-232. (rus)

[18] Gorsheneva O. V. Ehkonomicheskaya bezopasnost' regiona: problemy i perspektivy resheniya [Problems and prospects of solving the economic security of the region]. Izvestiya Yuzhnogo federal'nogo universiteta. Tekhnicheskie nauki. 2006. \# 17. - p. 228234. (rus)

[19] Dolmatov I. V. Formirovanie regional'noj sistemy obespecheniya ehkonomicheskoj bezopasnosti [Formation of regional economic security system]. Dissertaciya. ... kandidata ehkonomicheskih nauk Moskva: RGB. 2007. \# 151 s. (rus)
[20] Fridman Yu. A., Rechko G.N., Pimonov A. G. Competitive advantages and innovation in regional economies. Regional Research of Russia, 2012. - Vol.2. - No.3. - p.206-213.

[21] Fridman Yu.A., Rechko G.N., Pimonov A. G., Pisarov Yu. A. Ehkonomicheskaya zashchishchennost' Kuzbassa: ocenka i analiz [Evaluation and analysis of the economic security of Kuzbass]. Vestnik Kuzb. gos. texn. yniv. 2015. \# 2. - p. 133-140. (rus)

[22] Fridman Yu. A., Rechko G.N., Loginova E. Yu. Harakteristika osnovnyh ugroz razvitiyu Kuzbassa v usloviyah rezkogo izmeneniya konfiguracii vneshnih rynkov uglya [Characteristics of the main threats to the development of Kuzbass in a sharp change in the configuration of external coal markets]. Vestnik kuzbasskogo gosudarstvennogo tehnicheskogo univeristeta. 2013. \# 4. - p. 140-146. (rus)

[23] Fridman Yu. A., Rechko G.N., Pisarov Yu. A. Ehkonomicheskaya zashchishchennost' regiona: vvedenie $\mathrm{v}$ teoriyu [Introduction to the theory of economic security of the region]. Regional'naya ehkonomika. Yug Rossii. - Volgograd: Volgogradskij gosudarstvennyj universitet, 2013. \# 1. p. 23-29. (rus)

[24] Chernova L.S. Interrelation between the typology of the RF subjects and methods for the evaluation of the national economic level. Studies on Russian Economic Development. 2013. Vol. 24. No. 2. pp. 189198.

[25] Gosudarstvennaya programma Kemerovskoj oblasti «Ehkonomicheskoe razvitie i innovacionnaya ehkonomika Kuzbassa na 2014 - 2018 gody»).

[26] Dyuzhenkova N. V. Upravlenie ehkonomicheskoj bezopasnost'yu regiona $\mathrm{v}$ sovremennoj Rossii: avtoreferat dissertacii kandidata ehkonomicheskih nauk [Managing the economic security of the region in modern Russia]. Tambov, 2002. 16 s. (rus)

[27] Senchagov V. K. Ehkonomicheskaya bezopasnost' [Economic security]. - Moskva: Finstatinform, 1998. \# 621 s. (rus)

[28] Territorial'nyj organ Federal'noj sluzhby gosudarstvennoj statistiki po Kemerovskoj oblasti. Rezhim dostupa: http://kemerovostat.gks.ru (data obrashcheniya 25.01.2016). 
